Joanna GRZYBOWSKA-PIETRAS ${ }^{1}$, Patrycja DERBIN²

${ }^{1}$ University of Bielsko-Biala, Department of Civil Engineering, Willowa 2, 43-309 Bielsko-Biała, Poland

${ }^{2}$ Graduate of the University of Bielsko-Biala, Poland

ORCID / e-mail:

10000-0002-42538-3062 / jpietras@ath.bielsko.pl

\title{
Wpływ czasu użytkowania na właściwości włóknin Maliwatt stosowanych jako zabezpieczenie przeciwerozyjne skarp
}

\section{Słowa kluczowe:}

geowłóknina, biowłóknina, skarpa, erozja, biodegradacja, wytrzymałość, właściwości hydrauliczne

\section{Effect of time of use on properties of Maliwatt nonwovens used as slope erosion control}

Keywords:

geotextile, biononwovens, slope, erosion, biodegradation, tenacity, hydraulic properties

\begin{abstract}
The additional artificial elements have been implemented into weak soil to improve and stabilize the structures. The most frequent example is use of geosynthetics materials that increase stability, improve bearing capacity of soil, protect against surface erosion, affect into properties connected with filtration and drainage. The basic methods to protect against erosion of slopes is selected planting of grass and vegetation that prevent surface destruction. The application of biodegradable geotextiles allows to increase the positive impact on local stability of slopes. Advanced geotextiles support the vegetation growth by protection against dewatering. The geotextiles with grass seeds, biomates and fabrics made of natural fibers are frequently used in these applications. The physical, mechanical and hydraulic properties of applied materials should correspond to the purpose of built structure and type of soil.

The paper presents results of research of the Maliwatt type nonwovens. The analysis includes: the influence of different type of Maliwatt nonwovens and time of their use on selected physical, mechanical and hydraulic properties of these materials. The research was done by use of biotextile stitched with the Maliwatt technique that is available on the Polish market. The geotextiles were obtained from waste synthetic and natural nonwovens (RKL) with grass seeds, and innovative non-woven fabrics stitched with polyamide yarn (Maliwatt) obtained from low-quality washed sheep wool. The impact of the type of non-woven fabric on the growth of grasses was also analyzed. Research included spreading of 2 types of nonwovens on a natural slope with natural soil cover for 5 months period. All tests were performed in accordance with the applicable harmonized standards.
\end{abstract}




\section{WSTĘP}

Erozja jest naturalnym procesem, który występuje na Ziemi niezależnie od szerokości geograficznej, a jego przebieg oraz intensywność zależy m.in. od ukształtowania terenu, rodzaju gruntu, nawodnienia czy rodzaju pokrywy roślinnej. Przyczyny występowania zjawiska erozji mogą mieć charakter naturalny (wynikają z budowy geologicznej, działalności wody i wiatru), bądź są wynikiem gospodarczej działalności człowieka. Wysychanie gruntu w wyniku silnego nasłonecznienia, nagłe i intensywne opady deszczu oraz związane z tym zmiany poziomu wody gruntowej, wpływają na wystąpienie erozji powierzchniowej gruntu. Zjawisko to prowadzi między innymi do usunięcia ze skarp czy zboczy najcenniejszej, powierzchniowej warstwy gruntu, pogorszenia struktury skarp oraz niszczenia roślinności ochronnej [Schwarz i in. 2010].

Do zabezpieczenia skarp często stosowane są geosyntetyki, w tym geotekstylia, które pełnią przede wszystkim funkcję powierzchniowego zabezpieczenia przeciwerozyjnego. Materiały te są wykorzystywane zarówno do ochrony tymczasowej (biodegradowalne), jak i długotrwałej (niebiodegradowalne) [Chen i in. 2011, Álvarez-Mozos i in. 2014]. Do trwałej ochrony przed erozją wykorzystywane są najczęściej geosyntetyki zbudowane z materiałów o długotrwałej żywotności, takie jak: polipropylenowe lub poliestrowe przestrzenne maty antyerozyjne czy systemy geokomórkowe. Natomiast do tymczasowej ochrony przed erozją (od 1 do 3 lat) stosuje się geotekstylia otrzymane z surowców naturalnych (kokos, juta, bawełna, wełna), które w ciągu kilku lat od zainstalowania ulegają w gruncie całkowitej biodegradacji [Tauro i in. 2018].

W inżynierii lądowej geosyntetyki, w tym geotekstylia, pełnią wiele funkcji jednocześnie. Przykładowo geotekstylia stosowane w systemach ochrony przeciwerozyjnej na zboczach działają jako ochrona przed poślizgiem konstrukcji, jako filtr, chroniący podłoże przed wymywaniem cząstek gruntu (filtracja, drenaż), a także jako ochrona powierzchni skarpy [Erickson Paz i in. 2018]. Geosyntetyki zamontowane na zboczu zapewniają natychmiastową ochronę przed erozją. Geowłókniny, pełniące funkcję zabezpieczenia przeciwerozyjnego, powinny odznaczać się między innymi odpowiednią wytrzymałością oraz właściwościami hydraulicznymi, do których zaliczyć należy funkcję filtracji oraz drenażu [Grzybowska-Pietras i in. 2018]. Geotekstylia biodegradowalne wspierają roślinność ochronną, zmniejszając wymywanie nasion, a także zapewniając właściwy mikroklimat do ich kiełkowania i rozwoju.

Dokonanie wyboru zastosowania geowłóknin w konstrukcjach inżynierskich (skarpy nasypów i wykopów, nawierzchnie drogowe, drenaż) wymaga dużej wiedzy na temat funkcji, jaką mogą one pełnić, znajomości zasad projektowania oraz umiejętności określenia kluczowych parametrów materiału, decydujących o późniejszej bezpiecznej eksploatacji obiektu. Celem opisanych w dalszej części artykułu badań było rozpoznanie wpływu wybranych rodzajów włóknin oraz czasu ich eksploatacji na zmianę właściwości fizycznych, mechanicznych i hydraulicznych materiału oraz rozwój roślinności.

\section{MATERIAŁ I METODY BADAŃ}

\subsection{Materiał badawczy}

Do badań wykorzystano stosowaną obecnie w Polsce jako zabezpieczenie przeciwerozyjne skarp biowłóknię $\mathrm{RKL}$ otrzymaną $\mathrm{z}$ włókien z recyklingu ( $80 \%$ włókien syntetycznych, $20 \%$ włókien naturalnych - bawełnopochodnych), a także opracowaną w Katedrze Budownictwa Akademii Techniczno-Humanistycznej w Bielsku-Białej geowłókninę zbudowaną w $100 \%$ z odpadowych włókien wełny pranej niskiej jakości. W biowłókninie umieszczone 
zostały nasiona 7 gatunków traw, co ma istotny wpływ na poprawę procesu zadarnienia terenu. Włókniny wytworzono z wykorzystaniem technologii przeszywania (Maliwatt). Parametry fizyczne obu włóknin zamieszczono w Tab. 1.

Tab. 1. Parametry fizyczne włóknin.

Tab. 1. Physical parameters of nonwovens.

\begin{tabular}{|c|c|c|}
\hline \multirow{2}{*}{ Parametr } & \multicolumn{2}{|c|}{ Rodzaj materiału } \\
\hline & $\begin{array}{c}\text { biowłóknina } \\
\text { RKL } \\
\end{array}$ & $\begin{array}{l}\text { geowłóknina } \\
\text { wełniana }\end{array}$ \\
\hline Widok włókniny & & \\
\hline Skład surowcowy & $\begin{array}{l}\text { 1) } 80 \% \text { odpadowych } \\
\text { włókien syntetycznych } \\
\text { 2) } 20 \% \text { włókien naturalnych } \\
\text { (bawełnopochodnych) } \\
\text { z recyklingu odzieży } \\
\text { 3) nasiona traw }\end{array}$ & $\begin{array}{c}100 \% \text { wełny owczej prane } \\
\text { niskiej jakości }\end{array}$ \\
\hline Rodzaj przeszycia & $\begin{array}{l}\text { przędza poliamidowa; } \\
\text { splot trykot } 3,5 \mathrm{~mm}\end{array}$ & $\begin{array}{l}\text { przędza poliamidowa, } \\
\text { splot trykot } 7 \mathrm{~mm}\end{array}$ \\
\hline Masa powierzchniowa & $305,80 \mathrm{~g} / \mathrm{m}^{2}$ & $329,80 \mathrm{~g} / \mathrm{m}^{2}$ \\
\hline
\end{tabular}

\subsection{Stanowisko badawcze}

Próby polowe zrealizowano na terenie Akademii Techniczno-Humanistycznej w Bielsku-Białej w miesiącach od czerwca do listopada 2017 roku. W ramach realizacji eksperymentu przygotowano dwa pola o długości $2 \mathrm{~m}$, szerokości $1,5 \mathrm{~m}$ i głębokości $15 \mathrm{~cm}$. Następnie rozłożono biowłókninę RKL oraz geowłókninę wełnianą, przysypano każde z pól $10 \mathrm{~cm}$ warstwą gruntu wierzchniego i obsiano trawą skarpową (Rys. 1 i 2).

Określono podstawowe parametry gruntu, który wykorzystano w trakcie prac inżynierskich (wilgotność gruntu w, granicę płynności $w_{L}$, granicę plastyczności $w_{p}$ oraz wskaźnik plastyczności $I_{p}$ ). Oznaczono rozkład wielkości cząstek gruntu zgodnie z normą BS 1377:1990 i dokonano klasyfikacji gruntu. Parametry gruntu przedstawiają się następująco:

- rodzaj gruntu - CL;

- zawartość frakcji pylastej-8,40\%;

- zawartość frakcji piaszczystej-89,49\%;

- zawartość frakcji żwirowej-2,09\%;

- wilgotność gruntu w - 18,70\%;

- granica płynności $W_{L}-37,87 \%$;

- granica plastyczności $w_{p}-18,70 \%$;

- wskaźnik plastyczności $I_{p}-19,17 \%$. 


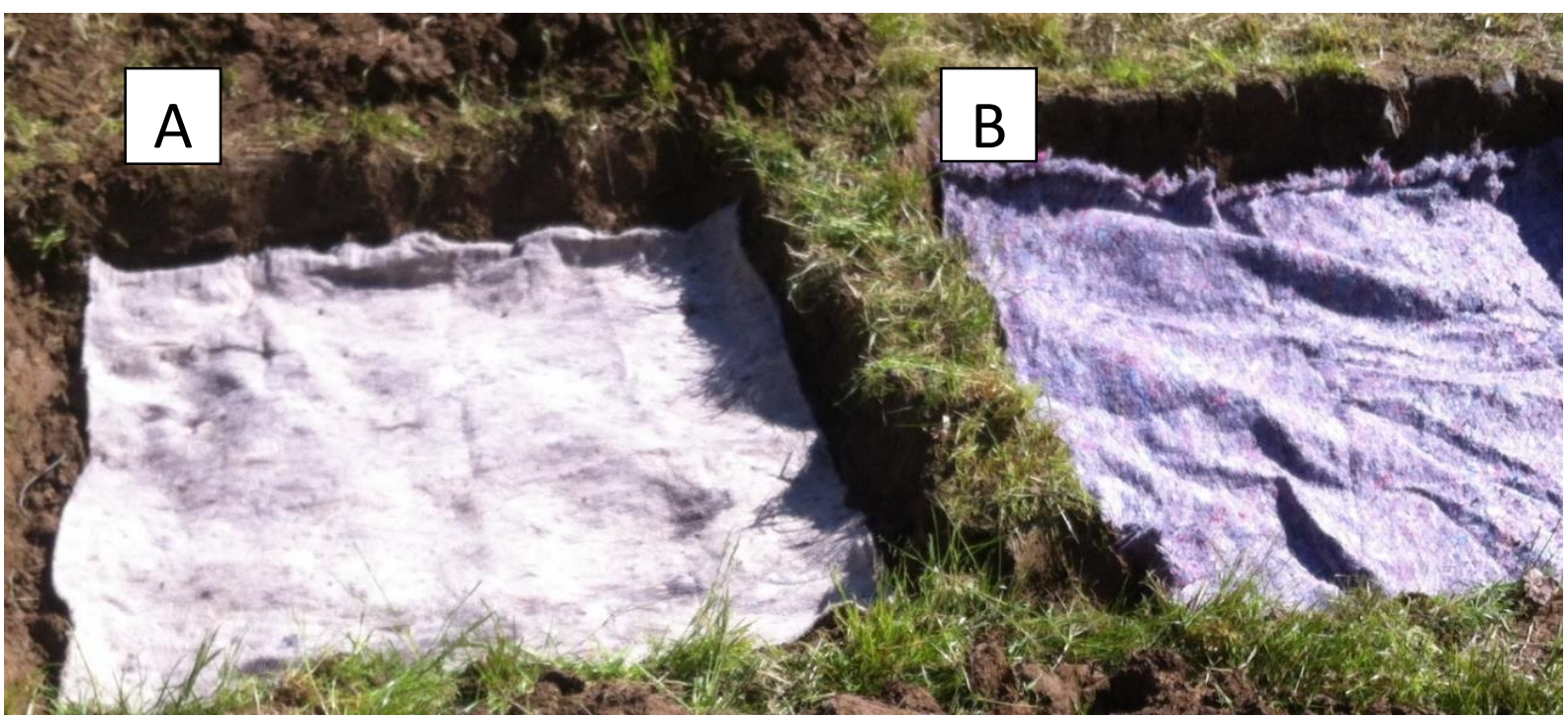

Rys. 1. Stanowisko badawcze: A) geowłóknina wełniana, B) biowłóknina RKL (fot. J. Grzybowska-Pietras).

Fig. 1. The test stand: A) woollen geo nonwoven, B) bio nonwoven RKL (photo by J. Grzybowska-Pietras)

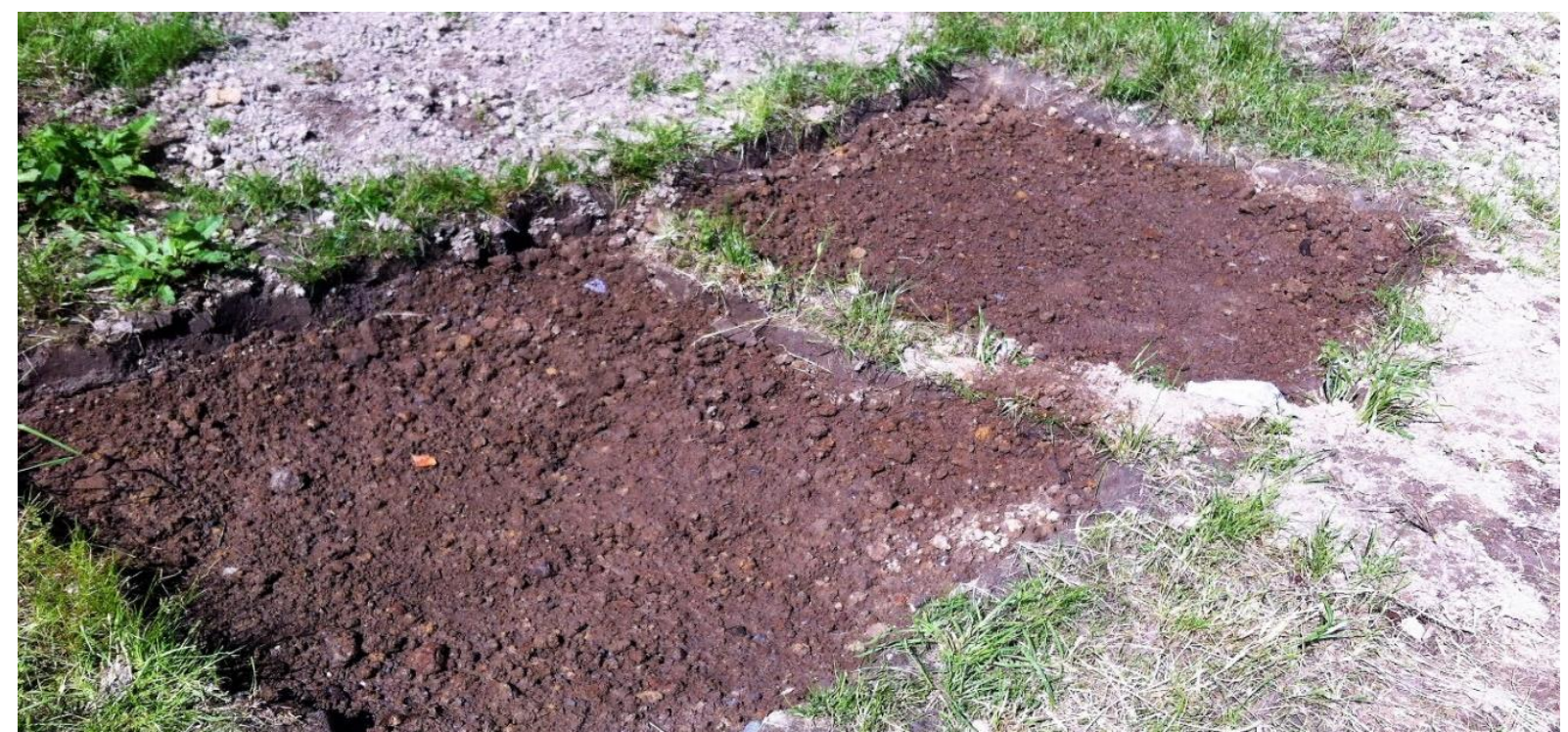

Rys. 2. Stanowisko badawcze z gruntem (fot. J. Grzybowska-Pietras).

Fig. 2. The test stand with soil (photo by J. Grzybowska-Pietras).

\subsection{Metodyka badań}

W celu oceny wpływu czasu eksploatacji na intensywność biodegradacji oraz zmianę właściwości mechanicznych i hydraulicznych analizowanych materiałów wykonano badania bio- i geowłókniny wzorcowej oraz materiałów po 5 miesiącach od zabudowania w gruncie (listopad 2017).

Badania przeprowadzono zgodnie z procedurami zawartymi w odpowiednich normach zharmonizowanych, odnoszących się do geotekstyliów i wyrobów pokrewnych. Badania laboratoryjne dotyczyły wyznaczenia zmian:

- masy powierzchniowej wg PN-EN ISO 9864:2007;

- grubości wg PN-EN ISO 9863-1:2016 (nacisk 2, 20 i 200 kPa);

- wytrzymałości na rozciąganie wg PN-EN ISO 10319:2015;

- wodoprzepuszczalności prostopadłej do powierzchni wyrobu wg PN-EN ISO 11058:2011. 


\section{WYNIKI BADAŃ I DYSKUSJA}

Po zakończeniu instalacji stanowisko badawcze w ciągu kolejnych 5 miesięcy było na bieżąco monitorowane. W dwunastym tygodniu od rozpoczęcia eksperymentu na powierzchni poletka z zainstalowaną geowłókniną wełnianą zaobserwowano intensywny wzrost trawy (Rys. 3).

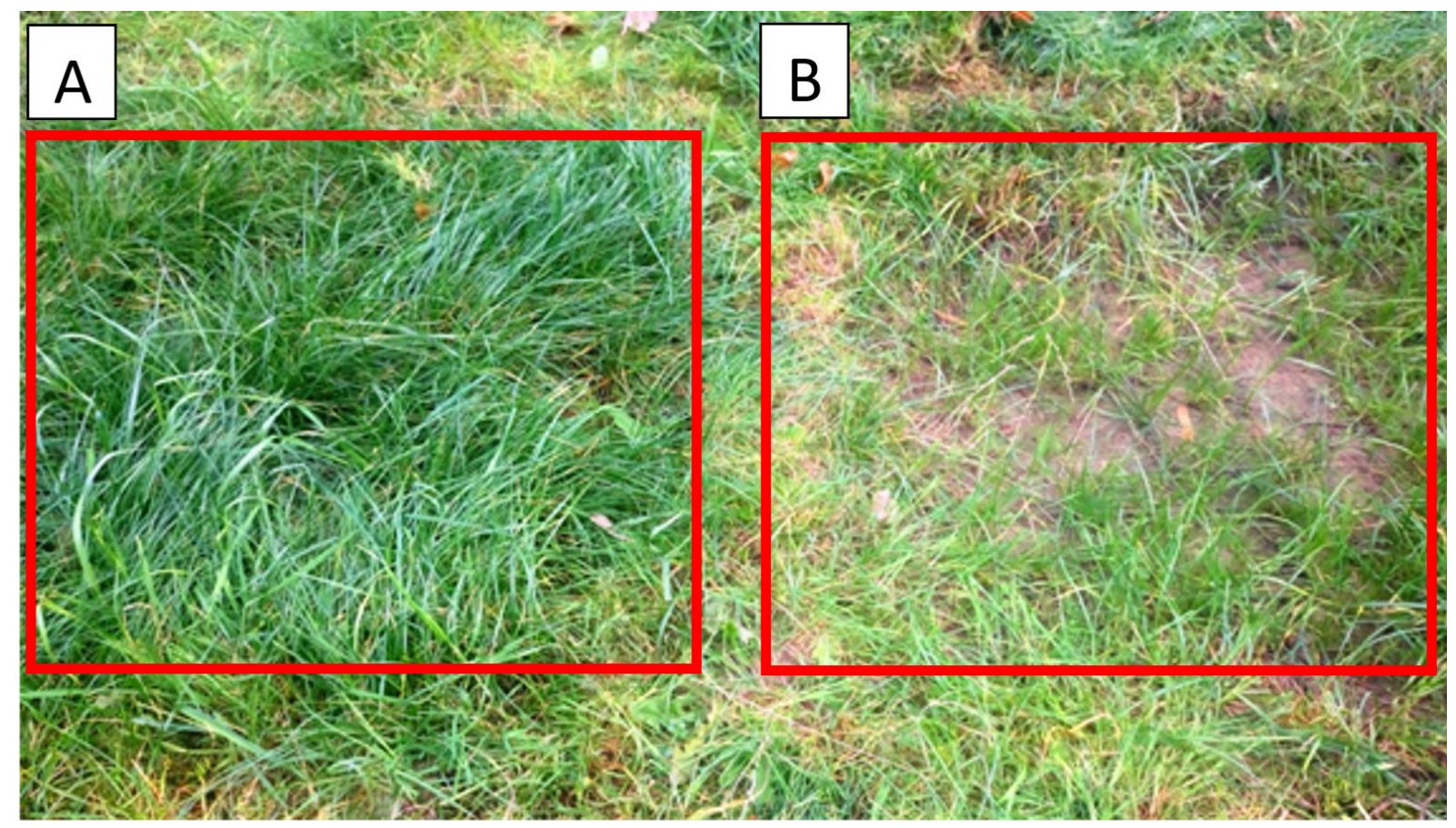

Rys. 3. Stanowsko badawcze po 3 miesiącach: A) geowłóknina wełniana,

B) biowłóknina RKL (fot. P. Derbin).

Fig. 3. The test stand after 3 months: A) woollen geo nonwoven, B) bio nonwoven RKL (photo by P. Derbin).

Zauważono, że w miejscu, gdzie zamontowano geowłókninę zbudowaną w 100\% z odpadowych włókien wełny trawa miała intensywny, ciemnozielony kolor, była znacznie wyższa od trawy, która wyrosła na biowłókninie RKL oraz posiadała bardzo rozbudowany system korzeniowy. Intensywny wzrost trawy, rozbudowaną sieć korzeni oraz jej barwę powiązano ze zwiększoną zawartością azotu uwalnianego w czasie rozkładu włókien wełnianych.

Po upływie pięciu miesięcy od dnia zainstalowania materiał badawczy wymontowano i wykonano badania wpływu rodzaju materiału oraz czasu eksploatacji w gruncie na wybrane właściwości fizyczne, mechaniczne i hydrauliczne obu włóknin (biowłóknina RKL, geowłóknina wełniana). Uzyskane wyniki badań przedstawiono w tabelach (Tab. 2 i 3) oraz w formie wykresów zamieszczonych na poniższych rysunkach (Rys. 4-6). 
Tab. 2. Wyniki badań biowłókniny RKL i geowłókniny wełnianej.

Tab. 2. Test results of bio nonwoven RKL and wollen geo nonwoven.

\begin{tabular}{|c|c|c|c|c|c|c|}
\hline \multirow{2}{*}{\multicolumn{2}{|c|}{ Rodzaj materiału }} & \multirow{3}{*}{$\begin{array}{c}\mathrm{Mp}\left[\mathrm{g} / \mathrm{m}^{2}\right] \\
305,8 \\
\end{array}$} & \multicolumn{3}{|c|}{ L [mm] } & \multirow{3}{*}{$\begin{array}{c}\text { Wzr } \\
\begin{array}{c}\text { wzdłuż / w poprzek } \\
{[\mathrm{kN} / \mathrm{m}]}\end{array} \\
2,3 / 0,9\end{array}$} \\
\hline & & & \multirow{2}{*}{$\frac{2 \mathrm{kPa}}{3,0}$} & \multirow{2}{*}{$\begin{array}{c}20 \mathrm{kPa} \\
1,9 \\
\end{array}$} & \multirow{2}{*}{$\frac{200 \mathrm{kPa}}{1,1}$} & \\
\hline \multirow{3}{*}{$\begin{array}{l}\text { Biowłóknina RKL } \\
\text { wzorzec }\end{array}$} & $\mathbf{x}$ & & & & & \\
\hline & $S$ & 41,8 & 0,1 & 0,1 & 0,1 & $0,2 / 0,1$ \\
\hline & $\mathrm{V}[\%]$ & 13,7 & 4,8 & 6,9 & 5,4 & $8,7 / 11,1$ \\
\hline \multirow{3}{*}{$\begin{array}{l}\text { Biowłóknina RKL } \\
\text { po } 5 \text { miesiącach }\end{array}$} & $x$ & 384,6 & 2,8 & 1,9 & 1,13 & $1,7 / 0,6$ \\
\hline & $S$ & 49,9 & 0,2 & 0,2 & 0,2 & $0,3 / 0,1$ \\
\hline & $\mathrm{V}[\%]$ & 12,1 & 8,5 & 11,2 & 14,8 & $17,6 / 16,7$ \\
\hline \multirow{3}{*}{$\begin{array}{c}\text { Geowłóknina } \\
100 \% \text { wełna } \\
\text { wzorzec }\end{array}$} & $x$ & 329,8 & 3,0 & 2,1 & 1,3 & $2,5 / 1,2$ \\
\hline & $S$ & 48,9 & 0,4 & 0,3 & 0,3 & $0,6 / 0,3$ \\
\hline & $\mathrm{V}[\%]$ & 14,8 & 11,7 & 16,8 & 21,9 & 23,2 / 24,8 \\
\hline \multirow{3}{*}{$\begin{array}{c}\text { Geowłóknina } \\
100 \% \text { wełna } \\
\text { po } 5 \text { miesiącach }\end{array}$} & $x$ & 268,8 & 2,7 & 1,8 & 1,2 & $0,8 / 0,4$ \\
\hline & $S$ & 25,7 & 0,2 & 0,2 & 0,1 & $0,2 / 0,1$ \\
\hline & $\mathrm{V}[\%]$ & 9,6 & 8,9 & 12,4 & 10,1 & $25,6 / 26,6$ \\
\hline
\end{tabular}

Objaśnienia: Mp - masa powierzchniowa, L - grubość, Wzr - wytrzymałość, X - wartość średnia, $\mathrm{S}$ - odchylenie standardowe, V - współczynnik zmienności.

Tab. 3. Zestawienie wyników wodoprzepuszczalności prostopadłej do powierzchni włóknin.

Tab. 3. The results of the measurement of water permeability characteristics normal to the plane of nonwovens.

\begin{tabular}{|c|c|c|c|}
\hline \multirow{2}{*}{ Miesiąc } & \multirow{2}{*}{$\begin{array}{l}\text { Wodoprzepuszczalność } \\
\text { prostopadła }\end{array}$} & \multicolumn{2}{|c|}{ Rodzaj materiału } \\
\hline & & $\begin{array}{c}\text { geowłóknina } \\
\text { wełniana }\end{array}$ & $\begin{array}{c}\text { biowłóknina } \\
\text { RKL }\end{array}$ \\
\hline \multirow{3}{*}{0} & $\mathbf{X}[\mathrm{m} / \mathrm{s}] \cdot 10^{-3}$ & 44,36 & 39,98 \\
\hline & $\mathrm{S}[\mathrm{m} / \mathrm{s}] \cdot 10^{-3}$ & 12,78 & 16,11 \\
\hline & $\mathrm{V}[\%]$ & 17,54 & 10,02 \\
\hline \multirow{3}{*}{6} & $\mathbf{X}[\mathrm{m} / \mathrm{s}] \cdot 10^{-3}$ & 69,81 & 28,03 \\
\hline & $\mathrm{S}[\mathrm{m} / \mathrm{s}] \cdot 10^{-3}$ & 15,21 & 7,84 \\
\hline & $\mathrm{V}[\%]$ & 24,58 & 9,74 \\
\hline
\end{tabular}

Objaśnienia: X - wartość średnia, S - odchylenie standardowe, V - współczynnik zmienności.

Na Rys. 4 przedstawiono wyniki badań wpływu czasu użytkowania na zmianę masy powierzchniowej włóknin w zależności od rodzaju surowca, z którego zostały wytworzone. Początkowa masa powierzchniowa przeszywanej geowłókniny wełnianej została określona na $329,8 \mathrm{~g} / \mathrm{m}^{2}$. Po upływie 5 miesięcy od zainstalowania, w wyniku biodegradacji w gruncie, masa wyrobu uległa zmniejszeniu o prawie 19\%. W przypadku wzorcowej, przeszywanej biowłókniny RKL (otrzymanej z odpadowych włókien syntetycznych i naturalnych) masa powierzchniowa wynosiła $305,8 \mathrm{~g} / \mathrm{m}^{2}$, a po określnym czasie uległa zwiększeniu do $394,6 \mathrm{~g} / \mathrm{m}^{2}$. Wzrost masy powierzchniowej w biowłókninie RKL jest wynikiem zakolmatowania geowłókniny w trakcie użytkowania cząstkami gruntu. 


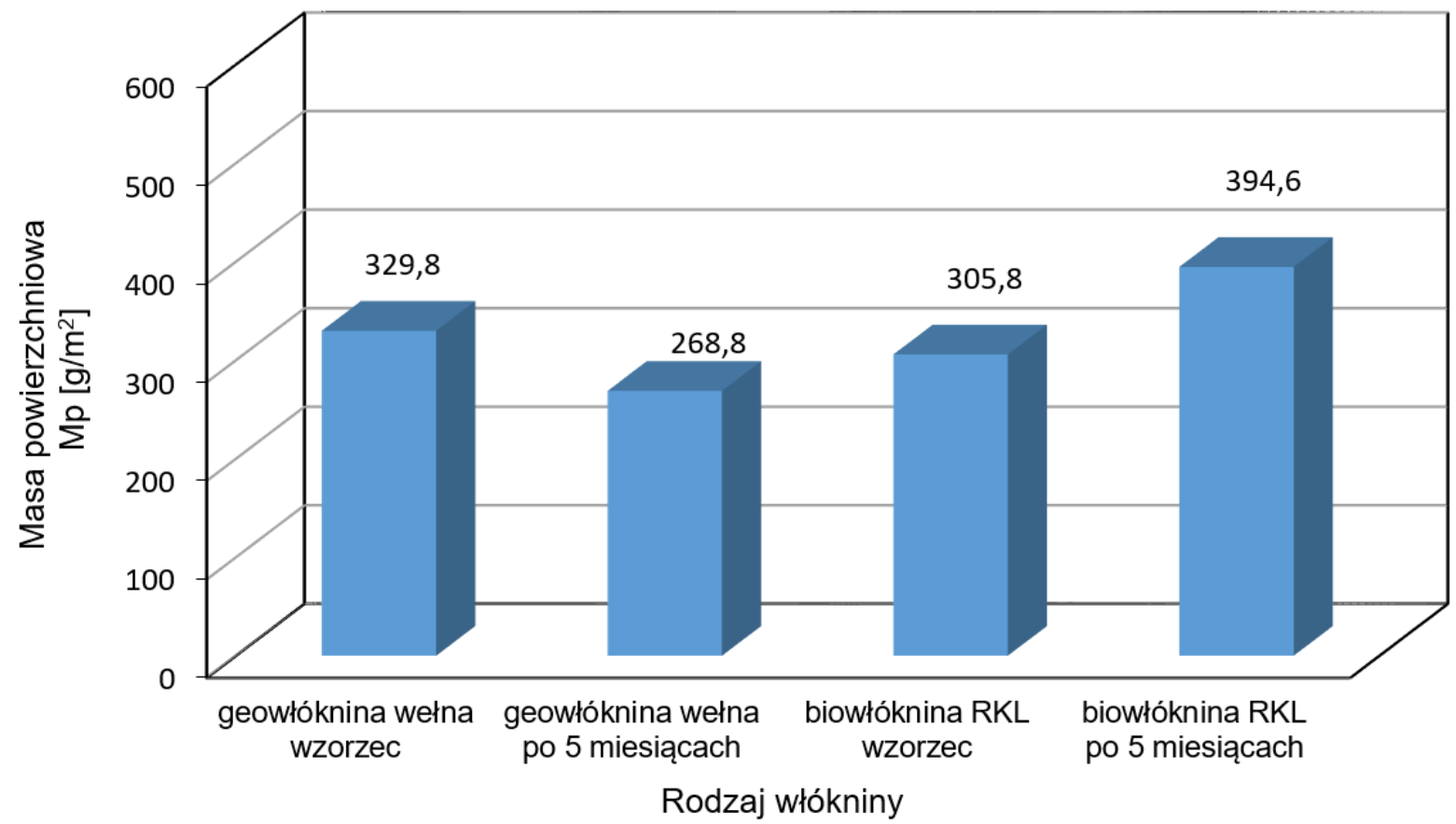

Rys. 4. Wpływ rodzaju włókniny i czasu użytkowania na masę powierzchniową.

Fig. 4. Influence of the type of nonwoven and time of use on surface mass.

Wpływ czasu użytkowania na wytrzymałość włóknin w zależności od kierunku zrywania zilustrowano na Rys. 5. Wytrzymałość obu wzorcowych włóknin (biowłóknina RKL i geowłóknina wełniana) była zbliżona do siebie i wynosiła: w kierunku wzdłużnym 2,3 kN/m (RKL) i $2,5 \mathrm{kN} / \mathrm{m}$ (wełna), a w kierunku poprzecznym odpowiednio $0,9 \mathrm{kN} / \mathrm{m}$ i $1,2 \mathrm{kN} / \mathrm{m}$. Po upływie 5 miesięcy od zainstalowania największy spadek wytrzymałości odnotowano dla geowłókniny wełnianej w obu analizowanych kierunkach (ponad 60\%).

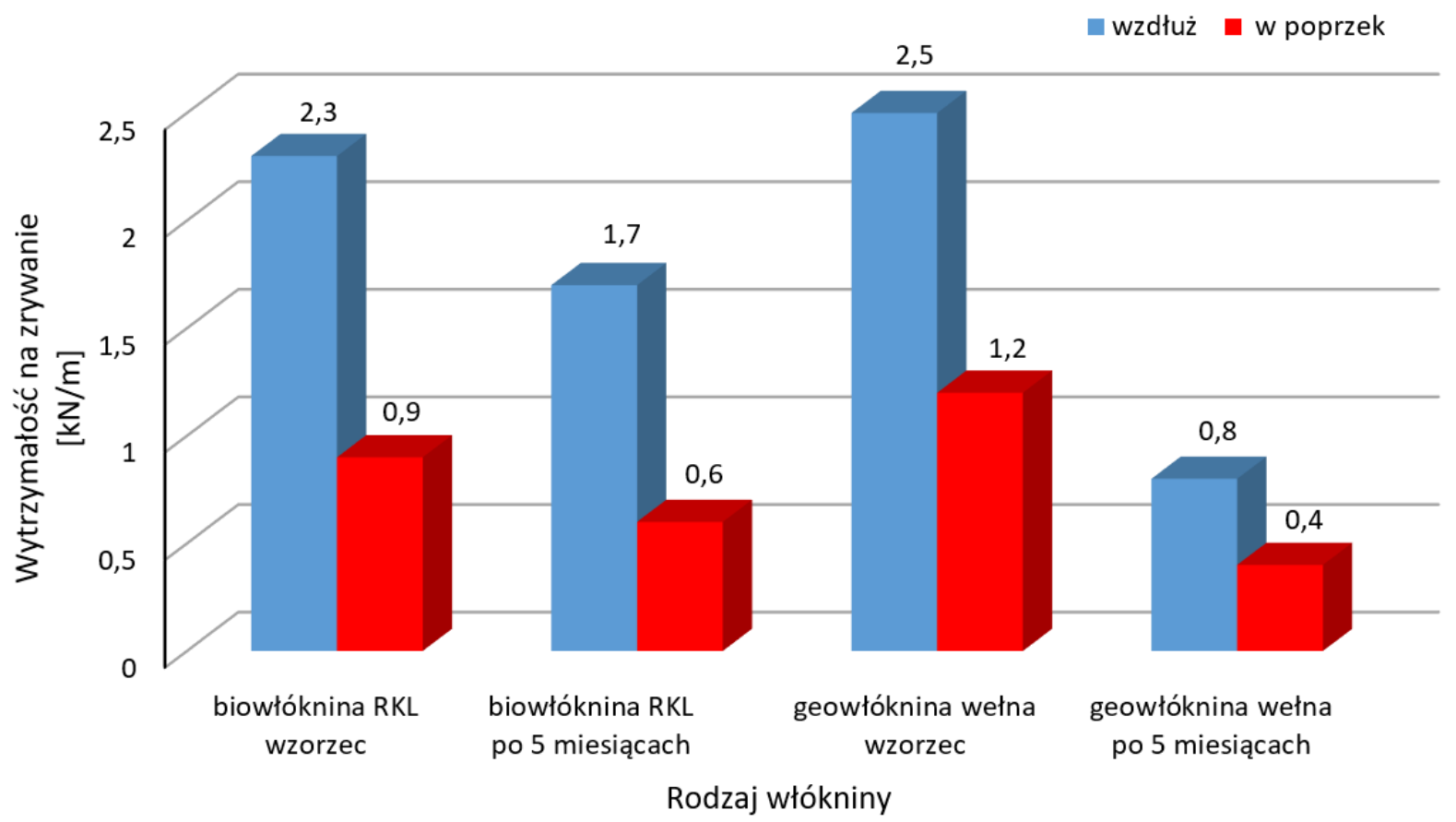

Rys. 5. Wpływ rodzaju włókniny i czasu użytkowania na wytrzymałość na zrywanie.

Fig. 5. Influence of the type of nonwoven and time of use on the tenacity. 
Geotekstylia, pełniące funkcję zabezpieczenia przeciwerozyjnego, powinny odznaczać się między innymi odpowiednimi właściwościami hydraulicznymi, do których zaliczyć należy funkcję filtracji i drenażu. Analizując uzyskane wyniki badań wpływu rodzaju materiału, jak i czasu użytkowania na właściwości hydrauliczne włóknin (Rys. 6), w tym wodoprzepuszczalności prostopadłej do powierzchni wyrobu bez obciążenia, zauważyć można, że początkowa prędkość przepływu wody przez włókniny wzorcowe, niezależnie od ich struktury, była zbliżona do siebie i wynosiła 0,049 m/s (biowłóknina RKL) i 0,046 m/s (geowłóknina wełna). W przypadku geowłókniny wełnianej po upływie 5 miesięcy analizowany parametr wzrósł o 59\% w stosunku do początkowych wartości wodoprzepuszczalności prostopadłej. W przypadku biowłókniny RKL prędkość przepływu wody przez materiał zmalała o prawie $49 \%$. Ponadto na zewnętrznej warstwie biowłókniny RKL widoczna była kolmatacja mechaniczna i biologiczna. Zatkanie materiału przez cząstki gruntu znacząco wpłynęło na spadek wodoprzepuszczalności.

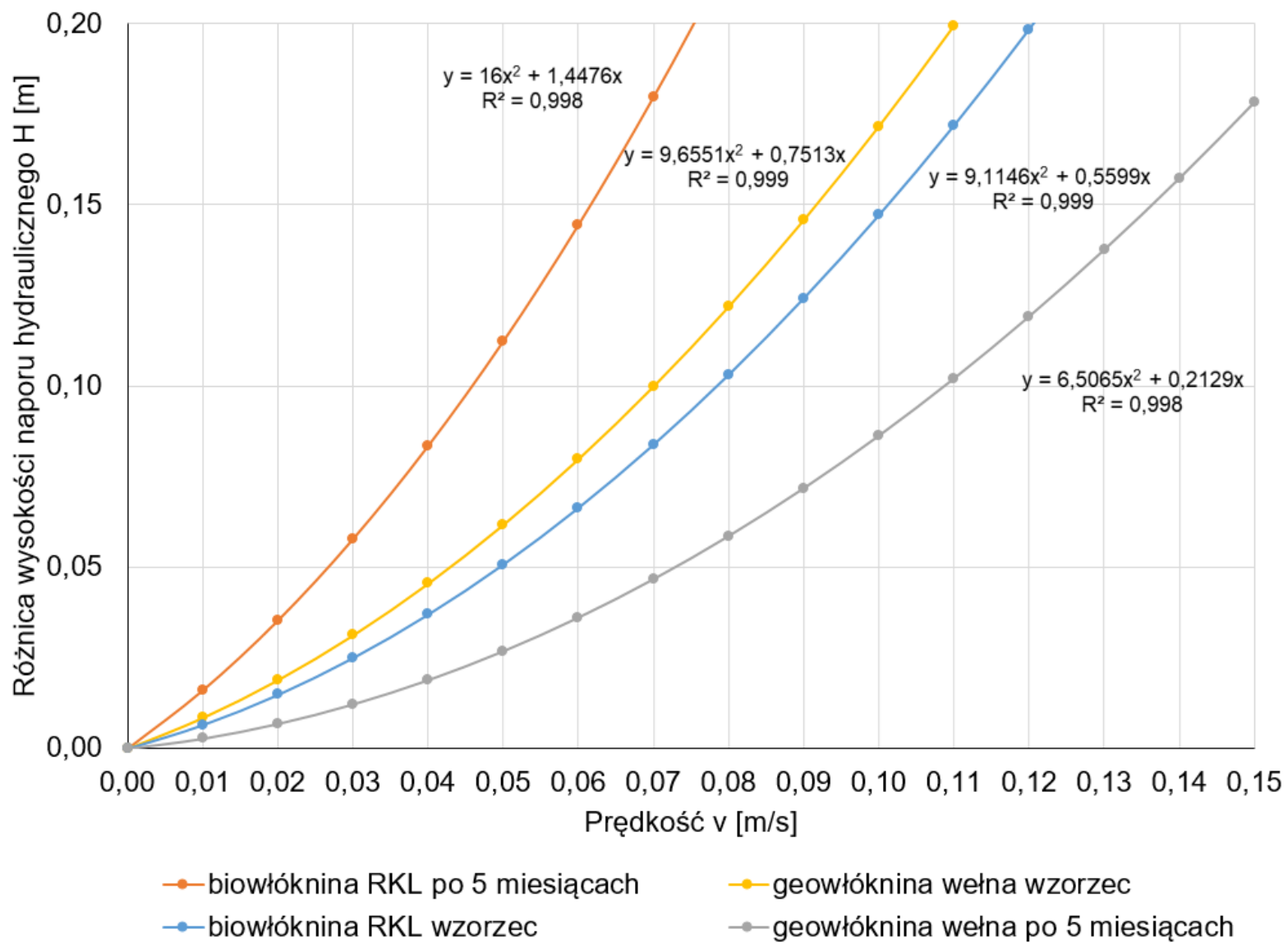

Rys. 6. Wpływ rodzaju włókniny na wodoprzepuszczalność prostopadłą do płaszczyzny wyrobu. Fig. 6. Influence of the type of nonwoven on water permeability normal to the plane.

\section{WNIOSKI}

1. Zastosowanie geowłókniny wełnianej otrzymanej z wełny pranej niskiej jakości wpływa na poprawę stateczności oraz zabezpieczenie przeciwerozyjne skarp.

2. Włóknina wełniana jest doskonałym nawozem dla roślinności skarpowej. W czasie deszczu włókna wełny absorbują nadmiar wody i magazynują ją, zapewniając w czasie suszy jej oddawanie do gruntu, co wpływa na poprawę warunków do rozwoju roślinności ochronnej. 
3. Włóknina wełniana w ciągu 5 miesięcy uległa znacznej degradacji, w wyniku której związki bogate w azot zostały uwolnione do gruntu. Związki te działają jak skuteczny nawóz, który wspiera wzrost trawy i znacznie przyspieszą jej zazielenienie. Geowłóknina z wełny wprawdzie uległa prawie całkowitej biodegradacji, ale w gruncie pozostała siatka (przeszycie), która stała się szkieletem dodatkowo zabezpieczającym konstrukcję skarp.

4. Zastosowanie włókniny wełnianej może być interesującą alternatywą w stosunku do obecnie stosowanych geotekstyliów biodegradowalnych wykorzystywanych jako funkcja zabezpieczenia przeciwerozyjnego skarp i zboczy.

\section{LITERATURA}

Álvarez-Mozos J., Abad E., Goñi M., Giménez R., Campo M.A., Díez J., Casalí J., Arive M., Diego I. 2014. Evaluation of erosion control geotextiles on steep slopes. Part 2: Influence on the establishment and growth of vegetation. Catena, 121, 195-203.

Chen S.C., Chang K.T., Wang S.H., Lin J.Y. 2011. The efficiency of artificial materials used for erosion control on steep slopes. Environmental Earth Sciences, 62, 197-206.

Erickson Paz F., Flor-Paz P., Almanzor N., Marcos M.C.M. 2018. Performance evaluation of soil erosion control geotextile materials on road cut slope. The 2018 World Congress on Advances in Civil, Environmental, \& Materials Research (ACEM18). Sondgo Convencia, Incheon, Korea, August 27-31, 2018.

Grzybowska-Pietras J., Nguyen G., Przybyło S., Rom M., Broda J. 2018. Properties of meandrical geotextiles designed for the protection of soil against erosion. E3S Web of Conferences, 49, 00042 (2018).

Schwarz M., Preti F., Giadrossich F., Lehmann P., Or D. 2010. Quantifying the role of vegetation in slope stability: A case study in Tuscany (Italy), Ecological Engineering, 36, 285-291.

Tauro F., Cornelini P., Grimaldi S., Petroselli A. 2018. Field studies on the soil loss reduction effectiveness of three biodegradable geotextiles. Journal of Agricultural Engineering, XLIX:799, 117-123.

PN-EN ISO 9863-1:2007. Geosynthetics - Determination of thickness at specified pressures - Part 1: Single layers, Warsaw, Polish Committee for Standardization.

PN-EN ISO 9864:2007. Geosynthetics - Test method for the determination of mass per unit area of geotextiles and geotextile-related products, Warsaw, Polish Committee for Standardization.

PN-EN ISO 10319:2015. Geosynthetics - Wide-width tensile test, Warsaw, Polish Committee for Standardization.

PN-EN ISO 11058:2011. Geotextiles and geotextile-related products - Determination of water permeability characteristics normal to the plane, without load, Warsaw, Polish Committee for Standardization.

BS 1377,1990. Methods of test for soils for civil engineering purposes. Part 2. Classification tests, London, British Standards Institution.

BS 5930,2015. Code of practice for ground investigations, London, British Standards Institution. 